\title{
Lessons for promotion of new agricultural technology: a case of Vijay wheat variety in Nepal
}

Krishna P. Timsina ${ }^{1 *}$, Yuga N. Ghimire', Devendra Gauchan², Sanjiv Subedi ${ }^{3}$ and Surya P. Adhikari ${ }^{4}$

\begin{abstract}
Background: Wheat is the third important cereal after rice and maize in Nepal. Its yield suffers from several factors such as lack of reliable irrigation, inclement weather, incidence of disease and lack of improved technology. New virulence race Ug99 (Uganda-99) has threatened all available commercial wheat varieties around the world and Asia. Some of the popular varieties of wheat in Nepal are also getting susceptible to different diseases. Vijay is one of the recently released first Ug99-resistant improved wheat varieties for Terai region in Nepal. Nepal has put special emphasis on the seed production and diffusion of this variety to promote rapidly in the farmers' fields to mitigate the potential epidemics of newly emerging pathotype of stem rust (Ug99). This variety is being promoted by several organizations and seed companies' before and after its release. Therefore, this study was undertaken to know the seed supply of Vijay and identify the factors that are contributing for its commercialization.

Methods: Sunsari, Morang, Rupandehi, Banke and Kailali districts were selected purposely representing Eastern, Western, Mid-western and Far-Western Terai regions of Nepal, respectively. Seed companies, agro-vets (input dealers) and cooperatives involved in Vijay seed multiplication and distribution in the respective districts were selected for the purpose of the study. From the list of agro-vets in respective study sites, a total of 87 wheat seed selling agro-vets were selected randomly as a sample. The sample survey covered $44 \%$ of the target population in both categories (dealers and non-dealers of national seed company). Out of total samples, $40 \%$ were national seed company dealer agro-vets, while $60 \%$ were non-dealers. Multivariate regression analysis was used to find out different factors responsible for commercialization of Vijay seed.
\end{abstract}

Results: Results indicate that about $67 \%$ of the agro-vets were involved in Vijay seed trading and their average time of involvement was 2.65 years. Majority of the agro-vets perceived this variety performed better than other existing popular varieties such as Gautam, Bhrikuti, Aditya and Nepal 297. However, there was still gap in timely supply of the seed. Based on the estimated Certified-1 seed production in 2015/16, Vijay must cover 56.88\% (11,943 ha) of total wheat area in Terai, but share of Vijay seed was about $22 \%$ of the total wheat seed sold by agro-vets in 2015/16. Nevertheless, it seems that this variety is getting popular in the study area compared to other improved wheat varieties in short time period. The factors influencing commercialization of Vijay were: agro-vets having dealership of national seed company, perception on comparative better performance of Vijay with Nepal 297, total quantity of wheat seed sold by agro-vets and total business transaction of the agro-vets. Moreover, other factors such as pre-release multiplication of Vijay variety by private seed companies and participation on seed related training have found positive contribution on its commercialization.

\footnotetext{
*Correspondence: krishnatimsina2000@gmail.com

${ }^{1}$ Socioeconomics and Agricultural Research Policy Division (SARPOD),

Nepal Agricultural Research Council (NARC), GPO 5459, Khumaltar,

Lalitpur, Nepal

Full list of author information is available at the end of the article
} 
Conclusion: It seems that the current production of Vijay's breeder seed is more than enough to cultivate in total wheat area in Terai of Nepal if proper seed cycle is maintained. But this is not in reality. NARC should decentralized foundation seed to private actors such as private seed companies, national seed companies and community-based organizations to maximize the resource use efficiency in the seed cycle through introducing effective monitoring and technical backstopping mechanism from public sector. Therefore, the close coordination and commitment of the public and private seed companies, community seed groups, cooperatives and public extension agencies to multiply seeds in subsequent cycles is required. Moreover, awareness program about superiority of Vijay with other improved wheat varieties should be emphasized for the rapid commercialization of the Vijay seed which would be an instrumental to mitigate the potential epidemics of newly emerging pathotype of stem rust (Ug99) in the future.

Keywords: Vijay, Seed flow, Dealership, Commercialization, Business transaction

\section{Background}

Wheat $(1,736,849 \mathrm{Mt}$.) is the third most important cereal after rice $(4,299,079 \mathrm{Mt}$.) and maize (2,231,517 Mt.), contributing $20 \%$ of the total cereal production in Nepal [17]. Over $60 \%$ of wheat is produced in the Terai (plain) region, though they are also produced in the mid hills and high hills regions of Nepal. Wheat yields suffer from some factors such as lack of reliable irrigation, inclement weather, incidence of disease and lack of improved technology [21]. NWRP [21] reported stem rust disease of wheat was under control since last six decades in a global basis. New virulence race Ug99 (Uganda-99) has threatened future wheat production, and it has posed new problem since all available commercial wheat varieties around the world and Asia in particular are susceptible to this new biotype of stem rust. Some of the popular varieties of wheat in Nepal are getting susceptible to different disease, e.g., Nepal 297 become susceptible to new biotypes of leaf rust, Bhrikuti moderately susceptible to foliar blight [17]. Therefore, new varieties with high yield potential and resistant to major diseases are needed to replace old varieties from the growers to increase the production and maintain at least the present productivity level [22].

In Nepal, both formal and informal types of seed system are prevailing. The informal seed system has been playing a significant role in fulfilling seed demand of the farmers [30]. Gauchan et al. [9] have reported that the formal sector representing public, private and community led seed system is becoming prominent in recent years, even though nearly $90 \%$ of the seed supply comes from traditional individual farmer-led model representing mainly informal farmer-based seed system. Until 2017, NARC has released and recommended 43 wheat varieties for different agro-ecological domains, i.e., 26 for Terai and 17 for hills. But, 13 wheat varieties have been denotified and only 30 varieties are under cultivation "Appendix 1" (Official record at NWRP, January 2018). Moreover, it is reported that, NWRP has produced 23 metric tons of wheat breeder seeds and 4.17 metric tons of nucleus seed of only 15 popular wheat varieties in 2015/16 due to shortage of land [23]. About $94 \%$ of wheat area was covered by modern varieties in the hills whereas it was $100 \%$ in the Terai plains [18]. Other studies at different districts indicate variation in coverage of modern varieties of wheat in Nepal which ranges from 65 to $95 \%$ in hilly districts and from 94 to $100 \%$ in different Terai districts [25, 31, 32, 35]. Gauchan [7] has reported more than 15 years age of most of commercially produced rice varieties in Nepal. Similarly, prevalence of older varieties with 12 years of adoption lags and 18 years of weighted varietal age in Nepal was reported by Gautam et al. [12] and Velasco et al. [36]. The adoption lags can be reduced to promote agricultural technologies using communitybased organizations and private seed companies [1, 2, 24]. About 27\% adoption gap of improved pigeon pea is reported in Malawi due to incomplete exposure to the improved pigeon pea varieties [26].

Vijay (BL 3063) is one of the recently released varieties in 2010 for Terai region in Nepal. It was the first Ug99resistant improved wheat variety developed and released in Nepal [15]. This is also resistant to leaf rust and moderately susceptible to yellow rust and tolerant to spot blotch (HLB) and suitable for harvesting using combined thresher [8]. It has rapid grain filling trait under heat stress conditions having good bread and chapati-making quality [19]. A recent expert elicitation study conducted by NARC-CIMMYT study in 2014 indicated that Vijay is becoming one of the popular wheat varieties in Nepal [8]. Out of several varieties released and disseminated in Nepal in the last 50 years, Vijay is one of the top 5 most popular varieties adopted in Nepal with area coverage of $6 \%$ in 2014 (Table 1). NWRP has reported about $21 \%$ of estimated area covered by Vijay variety in Nepal based on the supply of breeder seed in 2014.

High-quality genetically pure breeder and foundation seeds are produced mainly by NARC research stations to use for multiplication of next generation of commercial seeds (certified and improved). Recently, private seed companies and some cooperatives are also authorized to 
Table 1 Top five popular wheat varieties by agro-ecological domains and reasons for their popularity Source: Gauchan and Dongol (2015); based on Expert Elicitation Workshop, Kathmandu (2014)

\begin{tabular}{|c|c|c|c|c|}
\hline S. no & $\begin{array}{l}\text { Name } \\
\text { of popular } \\
\text { varieties }\end{array}$ & $\begin{array}{l}\text { Domains } \\
\text { or place name }\end{array}$ & $\%$ Area & Cause of popularity- or adopted attributes \\
\hline 1 & Gautam & Terai & 18.82 & Resistant to foliar leaf blight, heat tolerant, stay green, wide adaptation, high yield \\
\hline 2 & Nepal 297 & Terai & 17.40 & $\begin{array}{l}\text { Early maturity, good yielder even if later planted, terminal heat and hailstone tolerant, good } \\
\text { chapatti quality }\end{array}$ \\
\hline 3 & Bhrikuti & Terai & 13.61 & High yielding, drought tolerant, resistant to leaf and stripe rust \\
\hline 4 & WK 1204 & Mid hills & 12.51 & High yielder, Resistant to yellow rust, good bread quality \\
\hline 5 & Vijay & Terai & 5.80 & Resistant to Ug99 rust, tolerant to terminal heat, suitable to harvest using combined harvester \\
\hline
\end{tabular}

produce source seeds (mainly foundation) for subsequent cycle of seed multiplication with close supervision and monitoring of seed certifying agencies. Source seed is the initial generation high-quality genetically pure (breeder and foundation) seed used to produce next generation commercial (e.g., certified, improved) seeds of the same variety [14]. About 44 tons of source seed of Vijay were produced by research stations in Nepal and private seed agencies in 2009-2010 wheat seasons before its release in 2010 September [3]. Nepal has put special emphasis for the seed production and diffusion of this variety to promote rapidly in the farmers' fields to mitigate the potential epidemics of newly emerging pathotype of stem rust (Ug99). This variety is also being promoted by several organizations and seed companies' after release. This variety has highly potential for commercialization. Most of the past studies focused on general types of study on wheat variety adoption and farm level impacts [27, 31, 32]. Therefore, this study was undertaken to assess the importance of seed system development for rapid upscaling of new variety and identify the factors that are contributing to its commercialization.

\section{Methods}

\section{Selection of study sites and sample}

Command areas of the different research centers of Nepal Agricultural Research Council (NARC), viz. Bhairahawa (Rupandehi), Tarahara (Sunsari) and Nepalgunj (Banke), where Vijay variety was tested and being promoted by the NARC research stations and commodity programs were selected purposely for the study. Similarly, Sunsari, Morang, Rupandehi, Banke and Kailali districts were selected purposely representing Eastern, Western, Mid-western and Far-western Terai regions of Nepal as they represent the major wheat growing areas of the selected regions (Fig. 1). As this study focused on speed of seed flow and level of commercialization, agrovets (seed/input dealers) were selected as respondents rather than farmers. Seed companies, agro-vets (which are input dealers dealing mainly with agricultural inputs such as seeds, fertilizers, pesticides and veterinary medicines in Nepal.) and cooperatives involved in Vijay seed multiplication and distribution in the command areas of above-mentioned offices of NARC were selected to track the seed flow. From the list of agro-vets in respective study sites, a total of 87 wheat seed seller agro-vets including national seed company dealers were selected randomly. In totality, $44 \%$ samples of target population in both categories were selected. Out of total samples, $40 \%$ were national seed company (NSC) dealer agro-vets and $60 \%$ agro-vets were non-dealer agro-vets. The summary of the site selection and sampling technique is presented in Table 2.

\section{Techniques used in data collection and analysis}

Desk reviews were undertaken to understand and document varietal development, release and registration process and policies, importance of Ug99 resistant variety and tracking source seed production and multiplication by institutions in Nepal. Different published and unpublished documents of NARC and other institutions were reviewed related to wheat varietal development and dissemination process (focusing on pre-release and after release seed multiplication), including institutional constraints to rapid seed flow in relation to Vijay variety. Institutional survey was conducted with different agrovets and seed companies. Expert consultation meeting was done at each proposed districts with district agriculture development offices (DADO), plant breeders/ researchers and policy makers at central level to know the issues and challenges associated with Vijay variety of wheat in Nepal. After collecting the data, data were compiled, reviewed and cleaned before final analysis for the accuracy of the results. This study used both descriptive as well as inferential statistics. Multivariate regression analysis was used to find out different factors responsible for commercialization of Vijay seed. The details of the model are given below: 


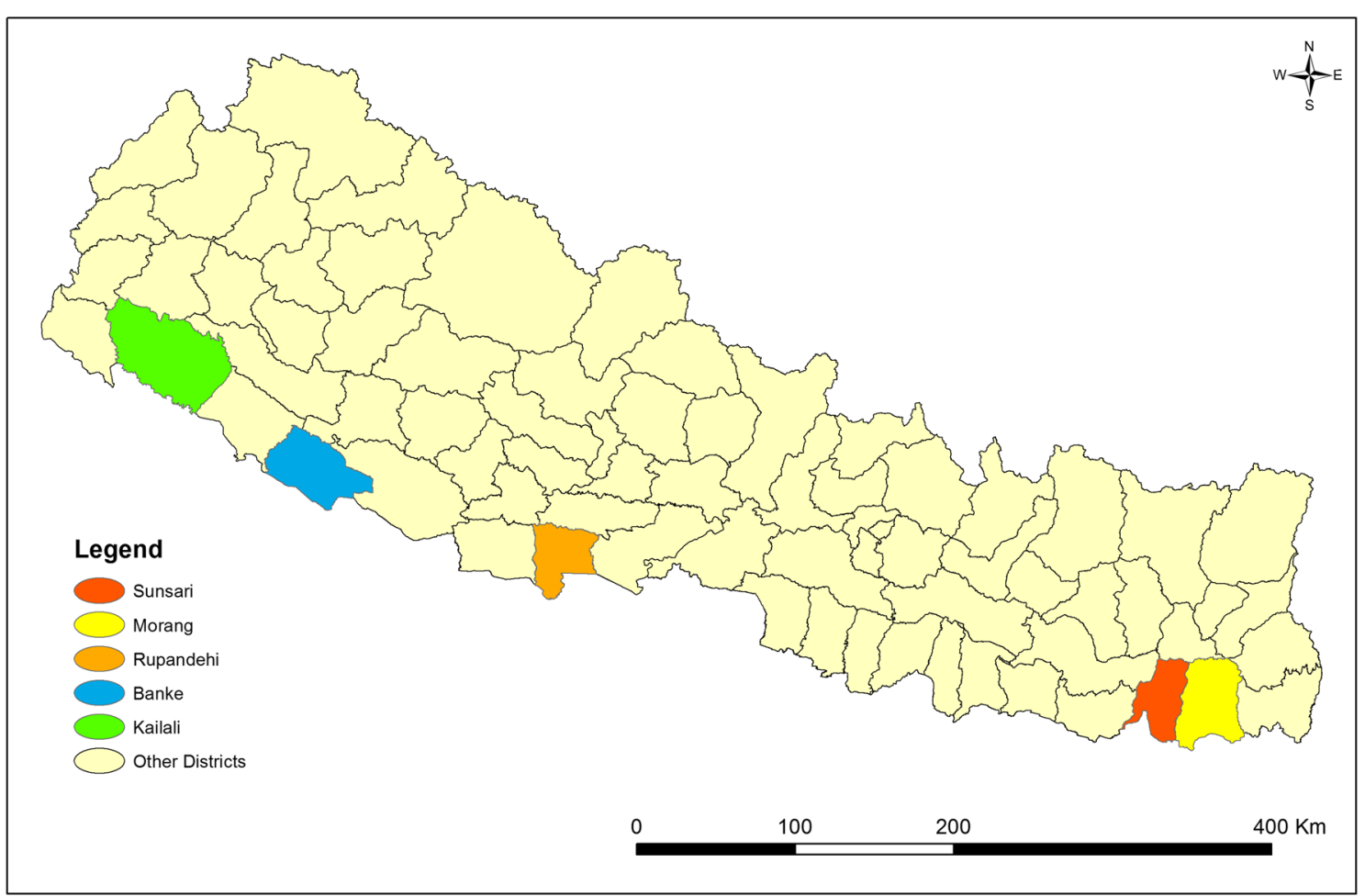

Fig. 1 Study areas showing in the map with different colors

Table 2 Details of NARC research stations, study area and sampling size and methods

\begin{tabular}{|c|c|c|c|c|c|c|c|c|}
\hline \multirow[t]{3}{*}{ Command area } & \multirow[t]{3}{*}{ Districts } & \multicolumn{4}{|l|}{ Agro-vets } & \multirow{3}{*}{$\begin{array}{l}\text { Seed } \\
\text { companies }\end{array}$} & \multirow[t]{3}{*}{ Professional } & \multirow[t]{3}{*}{ Methods } \\
\hline & & \multicolumn{2}{|c|}{ Target population (no) } & \multicolumn{2}{|c|}{ Sample size (no) } & & & \\
\hline & & Wheat seller ${ }^{\mathrm{a}}$ & NSC dealer & Wheat seller ${ }^{a}$ & NSC dealer & & & \\
\hline \multirow{2}{*}{$\begin{array}{l}\text { Regional Agriculture } \\
\text { Research Stations } \\
\text { (RARs) Tarahara }\end{array}$} & Morang & 15 & 16 & $7(47)$ & $6(38)$ & & 1 & $\begin{array}{l}\text { Purposive and Simple } \\
\text { random sampling }\end{array}$ \\
\hline & Sunsari & 15 & 10 & $11(73)$ & $8(80)$ & 1 & 2 & $\begin{array}{l}\text { Purposive and Simple } \\
\text { random sampling }\end{array}$ \\
\hline $\begin{array}{l}\text { National wheat } \\
\text { Research Program } \\
\text { (NWRP) }\end{array}$ & Rupandehi & 40 & 28 & $17(43)$ & $13(46)$ & 4 & 5 & $\begin{array}{l}\text { Purposive and Simple } \\
\text { random sampling }\end{array}$ \\
\hline \multirow{2}{*}{$\begin{array}{l}\text { Regional Agriculture } \\
\text { Research Stations } \\
\text { (RARs) Khajura }\end{array}$} & Banke & 18 & 1 & $9(50)$ & $0(0)$ & 1 & 2 & $\begin{array}{l}\text { Purposive and Simple } \\
\text { random sampling }\end{array}$ \\
\hline & Kailali & 35 & 19 & $10(33)$ & $6(32)$ & 1 & 2 & $\begin{array}{l}\text { Purposive and Simple } \\
\text { random sampling }\end{array}$ \\
\hline Total & & 123 & 74 & $54(44)$ & $33(44)$ & 7 & 12 & \\
\hline
\end{tabular}

a Dealership holder Agro-vets were excluded. Total wheat seller agro-vets $(n=54)$ and dealers $(n=33)$. Professionals such as seed specialists, wheat scientists and planners were also interviewed in different research stations, DADO and Kathmandu at NARC, MOAD, DOA. Figure in parenthesis indicates sample percentage

$\mathrm{TVS}=\alpha+\beta_{1} \mathrm{DNSC}+\beta_{2} \mathrm{DHQ}+\beta_{3} \mathrm{CVNL}+\beta_{4} \mathrm{TWS}+\beta_{5} \mathrm{AGP}+\beta_{6} \mathrm{DE}+\beta_{7} \mathrm{PT}+\beta_{8} \mathrm{DTV}+\beta_{9} \mathrm{PGV}+\beta_{10} \mathrm{BT}+\beta_{11} \mathrm{PSM}$

where TVS $=$ Total qty. of Vijay variety sold (Own + NSC) in 2015/16 in $\mathrm{kg}$ as a proxy for level of up-scaling,
DNSC $=$ Dealer of National Seed Company (1 if yes, otherwise 0$), \mathrm{DHQ}=$ Distance from district headquarter $(\mathrm{km}), \mathrm{CVNL}=$ Comparative performance of Vijay 
with Nepal 297 (1 if better than Nepal 297, otherwise $0)$, TWS = Total qty. of wheat seed (Own + NSC) sold in 2015/16 (kg), AGP = Age of the proprietor (year), $\mathrm{DE}=$ Duration of establishment (year), $\mathrm{PT}=$ participation on seed related training (1 if yes, 0 no), DTV $=$ Duration of involvement in Vijay Trading (year), PGV $=$ Perception on presence of required germination of Vijay ( 1 yes, 0 no), BT $=$ Business Transaction (Total Qty. of cereal seed sold in 2014/15 (kg), PSM = Pre-release seed multiplication by private seed company (yes 1, 0 otherwise), $\alpha$ and $\beta_{1} \ldots \beta_{11}=$ coefficient to be estimated.

\section{Results and discussion}

The details of socioeconomic and technical variables related to agro-vets surveyed are presented in Table 3. The education level of the agro-vets proprietor was more or less similar in the study area; on average, it was 11.82 years of education. Similar type of results was obtained in case of age of the proprietors. The wheat seller agro-vets were older (12.34 year) in RARS Tarahara area followed by NWRP area (9.37 year) and RARS Khajura area ( 9.32 year). The average transaction of seeds and cereals seed in 2014/15 by each agro-vet was about 25.05 Mt and 22.45 Mt, respectively, in the study area. About 10.97 Mt of wheat seeds was sold by agro-vets in 2015/16, which includes both subsidized seed provided by government of Nepal (GoN) and non-subsidized seed. Average quantity of subsidized Vijay seed $(4.28 \mathrm{Mt})$ sold by agro-vets in 2015/16 was higher than non-subsidized seed $(2.79 \mathrm{Mt})$. This quantity was higher than the Vijay seed sold in the year 2014/15 in both categories. Majority of the agro-vet proprietors (90\%) were received training related to seed production and marketing management. About $67 \%$ of the agro-vets were involved in Vijay seed trading, and their average time of involvement in Vijay trading was about 2.65 years. Seed company (SC) has been playing important role to create awareness about Vijay seed in the study area. About $85 \%$ of the agro-vets were selling Vijay seed in their own working single district, and they had mixed response about its availability on time, required quality and quantity. The Vijay variety is getting popular in the study area as more than $50 \%$ of the agro-vets had perceived that this variety performs better than other existing popular varieties such

Table 3 Description of socioeconomic and technical variables of sampled agro-vets Source: Field Survey (2016); SC $=$ Seed Company

\begin{tabular}{|c|c|c|c|c|}
\hline Description of variables & $\begin{array}{l}\text { RARS Tarahara Area } \\
(N=32)\end{array}$ & $\begin{array}{l}\text { RARS Khajura Area } \\
(N=25)\end{array}$ & $\begin{array}{l}\text { NWRP Area } \\
(N=30)\end{array}$ & Overall (87) \\
\hline Average qty. of total seed sold (Mt) in 2014/15 & 27.09 & 32.72 & 15.35 & 25.05 \\
\hline Average qty. of cereal seed sold (Mt) in 2014/15 & 26.68 & 32.26 & 14.42 & 24.45 \\
\hline Education level of respondents (Yrs.) & 11.75 & 12.48 & 11.33 & 11.82 \\
\hline Year of Establishment of agro-vets (Yrs.) & 12.34 & 9.32 & 9.37 & 10.45 \\
\hline Age of the respondents (Yrs.) & 39.97 & 37.28 & 42.80 & 40.17 \\
\hline Avg. qty. of wheat seeds sold (Mt) in 2015/16 & 10.80 & 10.91 & 11.18 & 10.97 \\
\hline Avg. qty. of Vijay sold in 2015/16 (subsidized seed excluded) & .922 & 2.24 & 4.22 & 2.79 \\
\hline Avg. qty. of Vijay sold in 2015/16 (only subsidized seed) & 2.22 & 8.50 & 1.60 & 4.28 \\
\hline Avg. qty. of Vijay sold in 2014/15 (subsidized seed excluded) & 1.13 & 2.10 & 2.68 & 2.01 \\
\hline Avg. qty. of Vijay sold in 2014/15 (only subsidized seed) & 2.80 & 5.80 & 1.67 & 2.34 \\
\hline$\%$ of Vijay selling on total wheat quantity (from & 10.00 & 31.00 & 24.00 & 21.66 \\
\hline Participation on training related to seed (Yes \%) & 81.2 & 96.0 & 93.3 & 89.7 \\
\hline Time of involvement in Vijay seed trading (Yrs.) & 2.74 & 2.48 & 2.74 & 2.65 \\
\hline Vijay seed selling status in 2015/16 (Yes \%) & 53.1 & 84.0 & 66.7 & 66.7 \\
\hline SC as a source of knowledge of Vijay (Yes \%) & 75.0 & 81.0 & 72.7 & 76.2 \\
\hline SC as a source of buying Vijay (Yes \%) & 50.0 & 95.0 & 50.0 & 65.5 \\
\hline Only one district as a selling destination of Vijay (Yes \%) & 70.0 & 86.7 & 94.7 & 86.4 \\
\hline Perception on availability of Vijay in required qty. (Yes \%) & 10.0 & 47.2 & 76.2 & 45.6 \\
\hline Perception on availability of Vijay on time (Yes \%) & 20.0 & 66.7 & 57.1 & 48.4 \\
\hline Perception on availability of Vijay in required quality (Yes \%) & 70.0 & 100.0 & 14.3 & 61.3 \\
\hline Perception on Vijay better than Gautam (Yes \%) & 55.0 & 62.5 & 84.2 & 67.3 \\
\hline Perception on Vijay better than Nepal 297 (Yes \%) & 30.0 & 71.4 & 57.9 & 53.3 \\
\hline Perception on Vijay better than Bhrikuti (Yes \%) & - & 100.0 & 63.2 & 72.0 \\
\hline Perception on Vijay better than Aditya (Yes \%) & 69.2 & 92.9 & 84.2 & 82.6 \\
\hline
\end{tabular}


as Gautam, Bhrikuti, Aditya and Nepal 297. Gauchan and Timsina [11] reported cost-benefit analysis of Vijay (2.33) in comparison with existing popular varieties like Gautam (2.12), Bhrikuti (2.19) and Nepal 297 (2.6) indicates that it is economically at par or superior in some specific cases when it is grown in medium land type with irrigation. Other than economic benefits, farmers prefer Vijay due to its bold grain, attractiveness, natural maturity and good taste of bread/chapatti. Moreover, it performs well and high yielding in medium land as compared to low land $[11,29]$.

\section{Commercialization prospective of Vijay seed}

Public sector research organizations such as NWRP and other research centers produce breeder and foundation seeds, while NSC, seed companies, cooperatives and producer groups mainly produce and multiply certified or truthfully labeled seeds. In addition to Vijay seed multiplication, its distribution and commercialization are important aspects. So to find out the different factors that contribute to upscale, the Vijay seed marketed and factors determining extent of marketing was analyzed using ordinary least square (OLS) regression. Total qty. of Vijay variety sold (Own + NSC) in 2015/16 was used as dependent variable and different explanatory variables such as dealer of national seed company, distance from district head quarter $(\mathrm{km})$, comparative performance of Vijay with Nepal 297, total qty. of wheat seed $($ Own + NSC) sold in 2015/16 (kg), age of the agro-vets proprietor (year), duration of agro-vets establishment (year), participation on seed related training (if yes 1), duration of involvement in Vijay seed trading (year), perception on presence of required germination of Vijay (if yes 1), total business transaction of the agro-vets (total qty. of seed sold in 2014/15 in kg) and pre-release seed multiplication by private seed company (if yes 1) were used as independent variables. To see the net effect of different variable, three models were run. Multicollinearity test was done among variable to increase the explanatory power of the model. The $F$ test shows that all three models are best fitted. In our analysis, we used the standardized coefficients to see the real effect of variable.

Agro-vets having dealership of national seed company were used as independent variable in model 1 , which is highly significant. The result shows 1 standard deviation (SD) increase in dealership of NSC, chances to increase in selling of Vijay seed by 0.426 SD compared to non-dealer agro-vets. This single variable covered the $18 \%$ variation of the model. In the last 3 years (2013/14-2015/16), there is increasing trend in the quantity of Vijay variety allocated by NSC. It was $10 \%$ of total wheat variety in $2013 / 14$ which was increased to $14 \%$ in $2015 / 16$.

In the second model, we had used distance of agro-vets from district head quarter and comparative performance of Vijay with Nepal 297 as a control variable to determine the net effect of dealership. In this model, the effect of dealership on selling of Vijay seed is still significant; however, its explanatory power decreased by 0.11 SD. Moreover, negative relationship between distance of agro-vets from district head quarter and Vijay selling quantity is observed. Comparative performance of Vijay with Nepal 297 is also contributing significantly on selling of Vijay variety; it shows $1 \mathrm{SD}$ increase in agro-vets who felt Vijay has better performance than Nepal 297, chance to increase in selling of Vijay Seed by 0.274 SD compared to agro-vets who felt worse performance of Vijay than Nepal 297. The second model is also best fitted, and the variation covered by the model is about $28 \%$.

Out of 11 variables used in model three, only three variables, viz. comparative performance of Vijay with Nepal 297, total quantity of wheat sold and total business transaction of the agro-vets, are found significant (Table 4). The explanatory power of comparative performance of Vijay with Nepal 297 is reduced by 0.28 SD than model 2 . The results show that $1 \mathrm{SD}$ increase in quantity of total wheat seed sold by agro-vets response to increase in Vijay sold by 0.560 SD. Similarly, 1 SD increase in total quantity of seed sold by agro-vets, chance to decrease in quantity of Vijay sold by $0.365 \mathrm{SD}$. It means, among the wheat seeds selling, agro-vets have been giving priority for Vijay seed; however, agro-vets who had higher business transaction give lesser priority for Vijay. It may be due to higher profit margin in vegetables and hybrid rice seed compared to wheat seed [9].

\section{Vijay seed multiplication and flow in the study area}

The Vijay variety of wheat was released in 2010. However, the seed multiplication of this variety was started before its release. National Wheat Research Program (NWRP) of Nepal Agricultural Research Council (NARC) is producing only breeder seed of this variety. In totality, it had provided Vijay breeder seed to seven private seed companies and four different Regional/Agricultural Research Stations (R/ARS) of NARC few years before release of this variety. Among the different private seed companies, Kalika Seed Company from Rupandehi district had started to multiply $40 \mathrm{~kg}$ of breeder seed in $2007 / 8$. It had produced foundation seed and then again multiply this foundation seed to $\mathrm{C} 1$ (Certified one) in own farm as well as in farmers field in contract production. In addition, different International Non-governmental organizations 
Table 4 Factors contributing for Vijay seed up-scaling for its commercialization

\begin{tabular}{|c|c|c|c|c|c|c|}
\hline \multirow[t]{2}{*}{ Variables } & \multicolumn{2}{|l|}{ Model 1} & \multicolumn{2}{|l|}{ Model 2} & \multicolumn{2}{|l|}{ Model 3} \\
\hline & $\begin{array}{l}\text { Standardized } \\
\text { coefficients }\end{array}$ & $P$ value & Standardized coefficients & $P$ value & Standardized coefficients & $P$ value \\
\hline (Constant) & $(1.858)$ & 0.069 & $(.742)$ & 0.461 & $(-1.264)$ & 0.213 \\
\hline $\begin{array}{l}\text { Dealer of National Seed Company (1 yes, } \\
0 \text { No) }\end{array}$ & $.426(3.490)$ & $0.001^{* * *}$ & $.415(3.563)$ & $0.001^{* * *}$ & $.116(.764)$ & 0.449 \\
\hline Distance of Agro-vets from DHQ (km) & & & $-.162(-1.392)$ & 0.170 & $-.029(-.236)$ & 0.814 \\
\hline $\begin{array}{l}\text { Comparative performance of Vijay with } \\
\text { Nepal } 297 \text { (if Better than Nepal } 297 \text { 1, } \\
\text { otherwise 0) }\end{array}$ & & & $.274(.742)$ & $0.022^{* *}$ & $.246(2.181)$ & $0.034^{* *}$ \\
\hline $\begin{array}{l}\text { Total qty. of Wheat seed (Own +NSC) sold } \\
\text { in 2015/16 (kg) }\end{array}$ & & & & & $.560(3.245)$ & $0.002^{* *}$ \\
\hline Age of the proprietor $(Y r)$. & & & & & $.159(1.258)$ & 0.215 \\
\hline Duration of establishment (Yr.) & & & & & $-.001(-.010)$ & 0.992 \\
\hline $\begin{array}{l}\text { participation on seed related training ( } 1 \\
\text { yes, } 0 \text { no) }\end{array}$ & & & & & $.096(.745)$ & 0.460 \\
\hline $\begin{array}{l}\text { Duration of involvement in Vijay Trading } \\
\text { (Yr.) }\end{array}$ & & & & & $-.032(-.243)$ & 0.809 \\
\hline $\begin{array}{l}\text { Perception on presence of required germi- } \\
\text { nation of Vijay ( } 1 \text { yes, } 0 \text { no) }\end{array}$ & & & & & $.004(.037)$ & 0.970 \\
\hline $\begin{array}{l}\text { Business Transaction (total qty. of cereal } \\
\text { seed sold in 2014/15 (kg) }\end{array}$ & & & & & $-.365(-2.718)$ & $0.009^{* *}$ \\
\hline $\begin{array}{l}\text { Pre-release seed multiplication by Private } \\
\text { Seed Company (yes 1, } 0 \text { otherwise) }\end{array}$ & & & & & $.070(.401)$ & 0.690 \\
\hline Fvalue & 12.18 & $0.001^{* * *}$ & 7.11 & $0.000^{* * *}$ & 4.39 & $0.000^{* * *}$ \\
\hline$R$ square & .181 & & .287 & & .490 & \\
\hline Adjusted $R$ square & .166 & & .247 & & .366 & \\
\hline
\end{tabular}

${ }^{* *}$ and ${ }^{* *}$ mean significant at $1 \%$ and $5 \%$ level of significance; Figure in parenthesis indicates the $t$ value

(I/NGOs) and projects played important role to multiply this variety before its release. For example, out of 18 , $486 \mathrm{~kg}$ seed produced by Kalika Private Seeds Company, about $11,986 \mathrm{~kg}$ seed was purchased by different organizations using USAID-Famine Seed Project funds for further pre-release seed multiplication in the 2009-2010 cycle [16]. Farmers were also actively participated in its multiplication through participatory varietal selection. NWRP had distributed about $3382 \mathrm{~kg}$ of breeder seed to different private seed companies and R/ARS for its multiplication before release of this variety.

After release of this variety, more private seed companies are attracted and different R/ARS of NARC have been involved to multiply this variety to commercialize it. Until 2016, about 15 private seed companies and $11 \mathrm{R} /$ ARS of NARC have been involved to produce foundation seed of this variety. Moreover, national seed company and other I/NGOs have been involved to produce foundation seed to fulfill their program requirements. The $\mathrm{C} 1$ seed of Vijay variety has been produced through different modalities such as contract production of private seed companies with farmers, private Seed Companies' own farm, contract production of District Agriculture Development Offices (DADOs) with farmers group, community-based seed multiplication, contract production of agro-vets with farmer and production on national seed company's own farm "Appendix 2."

Until 2015/16, NWRP has produced 29 Mt of Vijay's breeder seed. One ton of breeder seed and $15 \mathrm{Mt}$ of foundation seed is adequate to meet the $5 \%$ wheat area (36,000 ha) for Nepal if seed multiplication occurs regularly in the prescribed seed multiplication ratio (1:15) and prescribed seed cycle (breeder to foundation and foundation to certified seeds ( $\mathrm{C} 1$ and $\mathrm{C} 2)$ with proper planning and coordination [11]. Based on this assumption and availability of breeder seed, it is estimated that about 62 Mt foundation seed, $1710 \mathrm{Mt} \mathrm{C1}$ seed and 21,498 Mt C2 seed available in the market which is more than enough to cover the total wheat area in Nepal. However, production of $\mathrm{C} 2$ seed was not in practice in the field even it is the component of seed cycle. Moreover, based on the estimated C1 seed in 2015/16, it must cover $56.88 \%$ 
(11,943 ha) of total wheat area by Vijay variety in Terai "Appendix 3". It is found that Vijay wheat variety covers about $22 \%$ of the share on total wheat seed sold by agrovets in 2015/16. An expert panel interview carried out for this study in the study areas expressed about $17 \%$ area covered by Vijay variety. Similarly, a national level expert elicitation conducted by CIMMYT-NARC collaborative study under Standing Panel Impact Assessment of the CGIAR (SIAC) in Nepal estimated $5.8 \%$ of the wheat area in Nepal in 2014 [8].

It shows inefficiency of the national $R \& D$ organization in the promotion and use of Vijay seed in the country. Similar result was reported by Ghimire et al. [13] and Timsina et al. [33, 34]. Little interaction and communication among various actors within the seed delivery chain resulted in a weak system that supplies less than $20 \%$ of seed requirement of farmers [4, 20]. Farmer seed networks can function efficiently in varietal diffusion [5]. Innovative platforms should be established in order to facilitate open communication and dialogue among all actors in the seed delivery system for its effective delivery [6]. Gauchan et al. [10] reported that well-planned strategies are required for further use of breeder's seeds and suggested to introduce mechanism of providing incentive and penalties for proper utilization of breeder to produce foundation seed by concerned agencies.

Proper planning and distribution of Vijay seed is required to create efficiency in resources use in the different research stations of NARC. If breeder seed is not available in all NARC stations, proper coordination and monitoring mechanism should be developed to produce breeder seed. It will also solve the current problem of land shortage to produce source seed in some of the research stations of NARC. Foundation seed production and supply should be decentralized to private actors such as private seed companies, national seed companies and community-based organization (CBOs) to maximize the resource use efficiency in the seed cycle. Therefore, the commitment of the public and private seed companies, community seed groups, cooperatives and public extension agencies to multiply seeds in subsequent cycles is required. The support for processing and storage, awareness about improved seed technologies and mechanization for foundation and certified seed is required at community level for community-based seed production [10]. SARPOD [28] has also emphasized to focus on production of breeder seed by NARC and foundation seed by private seed companies to capture their comparative advantages and promote resource use efficiencies. In addition, public-private and community partnership in seed production and supply and developing network of diverse set of actors and institutions are required to meet the demand and supply of quality seed in required time. Gauchan [10] highlighted that strengthening breeding by public sector, seed multiplication by community sector and marketing by private sector are required for sustainable seed business in Nepal. The details of Vijay seed flow are presented in "Appendix 2."

\section{Conclusions}

Vijay is the first Ug99-resistant wheat variety developed and released in Nepal by NARC in 2010. However, the seed multiplication of this variety started before its release since 2007/8 through the involvement of private seed companies. Until 2010, about three Mt. of breeder and seven Mt. of Foundation seed had already been produced for its rapid dissemination before its release. About $67 \%$ of the agro-vets were involved in Vijay seed trading, and their average time of involvement was about 2.65 years. More than $50 \%$ of the agro-vets perceived that this variety performed better than other existing popular varieties such as Gautam, Bhrikuti, Aditya and Nepal 297. However, there is still mismatch between demand and supply of seed. Based on the availability of breeder seed of Vijay, it is estimated that about $62 \mathrm{Mt}$ foundation seed, $1710 \mathrm{Mt}$. C1 seed and 21,498 Mt. C2 seed available in the market in 2015/16, which is more than enough to cover the total wheat area in Nepal. However, production of $\mathrm{C} 2$ seed was not in practice recently in the field even it is the component of seed cycle. Moreover, based on the estimated $\mathrm{C} 1$ seed in $2015 / 16$, it must cover $56.88 \%$ (11,943 ha) of total wheat area by Vijay variety in Terai. But it has been found that Vijay seed shared about 22\% on total wheat seed sold by agro-vets in 2015/16 and actual farm level use and adoption is estimated to be much lower. Regression analysis showed that presence of dealership of agro-vets with national seed company, relative performance of Vijay with Nepal 297, quantity of wheat seed sold by agro-vets were found to have significant positive contribution on Vijay seed sold. Similarly, total business transaction of the agro-vets was found to have significant negative contribution on Vijay seed selling. Among the wheat seeds, agro-vets has been giving priority to Vijay seed; however, agro-vets who had higher business transaction gave lesser priority to Vijay. It may be due to higher profit margin in vegetables and hybrid 
rice seed compared to wheat seed. In addition, other factors such as pre-release multiplication of this variety by private seed companies and participation on seed related training have found positive contribution on the commercialization of Vijay variety. This implies that future crop varietal improvement research program should focus on pre-release seed multiplication and fast-track release to rapidly promote commercialization of the crop varieties in the short period.

Moreover, from an analysis, we can conclude that the proper planning and distribution of Vijay seed is required to create resource use efficiency in the different research stations of NARC. NARC as a public research agency with expertise in plant breeding should focus only on breeder seed production, while foundation seed should be decentralized to private actors to increase resource use efficiency in the seed cycle. Therefore, close coordination and commitment from the private seed companies, national seed companies and community-based organization (CBOs) such as community seed groups, cooperatives and public extension agencies is required to multiply seeds in subsequent cycles. Furthermore, awareness program comparing good varietal traits of Vijay with other improved wheat varieties should be emphasized to accelerate the dissemination of Vijay seed rapidly in the country which would be an instrumental to mitigate the potential epidemics of newly emerging pathotype of stem rust $(\mathrm{Ug} 99)$ in the future.

\section{Abbreviations}

CBOs: community-based organizations; DADO: District Agriculture Development Office; GoN: Government of Nepal; I/NGOs: International/Non-governmental organizations; NARC: Nepal Agricultural Research Council; NWRP: National Wheat Research Program; PSC: Private seed company; NSC: National seed company; FG: Farmers Group; RARS: Regional Agricultural Research Station; SARPOD: Socioeconomics and Agricultural Research Policy Division; SC: Seed company; SD: Standard deviation.

\section{Authors' contributions}

KPT was the lead investigator and the initiator of the study also responsible for literature search and write-up and finalization of the manuscript. YNG and DG were responsible for the overall study design and provided critical feedback on the manuscript. SS and SPA were responsible for filed study and drafting manuscript. All authors read and approved the final manuscript.

\section{Author details \\ 1 Socioeconomics and Agricultural Research Policy Division (SARPOD), Nepal Agricultural Research Council (NARC), GPO 5459, Khumaltar, Lalitpur, Nepal. 2 Bioversity International Nepal Office, National Agriculture Genetic Resource Centre, Khumaltar, Lalitpur, Nepal. ${ }^{3}$ Regional Agricultural Research Station (RARS, Nepalgunj), Nepal Agricultural Research Council (NARC), GPO 5459, Khumaltar, Lalitpur, Nepal. ${ }^{4}$ Regional Agricultural Research Station (RARS, Tarahara), Nepal Agricultural Research Council (NARC), GPO 5459, Khumaltar, Lalitpur, Nepal.}

\section{Acknowledgements}

We are grateful for the financial support from NARC for enabling the collection of data. We thank all respondents who were participated in the study. We would like to thank Mr. Jeevan Lamichhane for his suggestions.

\section{Competing interests}

The authors declare that they have no competing interests.

\section{Availability of data and materials}

The datasets used and/or analyzed during the current study are available from the corresponding author on reasonable request.

\section{Consent for publication}

All authors agree and consent for the article to be published.

Ethical approval and consent to participate

Oral informed consent was obtained from each respondent from each of the participating agro-vets and other stakeholders.

Funding

The funding was provided by Nepal Agricultural Research Council (NARC).

\section{Appendix 1}

See Table 5. 
Table 5 Released wheat varieties in Nepal that are cultivated since 1960-2017

\begin{tabular}{|c|c|c|c|c|c|}
\hline S. no & Variety & Origin & Released year & Recommendation domain & $\begin{array}{l}\text { Grain yield } \\
\text { (ton/ha) }\end{array}$ \\
\hline 1 & Lerma 52 & Mexico & 1960 & Hills & 5.0 \\
\hline 2 & RR 21 & India & 1971 & Terai & 4.0 \\
\hline 3 & UP 262 & India & 1978 & Terai & 4.0 \\
\hline 4 & Nepal 297 & India & 1985 & Terai & 5.0 \\
\hline 5 & Annapurna 1 & Mexico & 1988 & Hills & 5.5 \\
\hline 6 & Annapurna 3 & Mexico & 1991 & Hills & 5.5 \\
\hline 7 & BL 1022 & Nepal & 1991 & Western Terai & 5.0 \\
\hline 8 & Bhrikuti & Mexico & 1994 & Terai & 5.0 \\
\hline 9 & BL 1135 & Nepal & 1994 & Terai & 5.0 \\
\hline 10 & Annapurna 4 & Mexico & 1994 & Hills & 5.0 \\
\hline 11 & Achyut & India & 1997 & Terai & 4.5 \\
\hline 12 & Rohini & Nepal & 1997 & Terai & 4.1 \\
\hline 13 & Kanti & Mexico & 1997 & Hills & 5.5 \\
\hline 14 & Pasang Lhamu & Mexico & 1997 & Hills & 6.7 \\
\hline 15 & BL 1473 & Nepal & 1999 & Terai & 4.0 \\
\hline 16 & Gautam & Nepal & 2004 & Terai & 4.3 \\
\hline 17 & WK 1204 & Mexico & 2007 & Hills & 4.3 \\
\hline 18 & NL 971 & Mexico & 2009 & Terai & 4.5 \\
\hline 19 & Aditya (BL 3264) & Nepal & 2009 & Terai & 4.8 \\
\hline 20 & Vijay (BL 3063) & Nepal & 2010 & Terai & 4.5 \\
\hline 21 & Gaura (BL 3235) & Nepal & 2012 & Hills & 5.0 \\
\hline 22 & Dhaulagiri (BL 3503) & Nepal & 2012 & Hills & 4.9 \\
\hline 23 & Danphe (NL 1064) & Mexico & 2015 & Hills & 4.5 \\
\hline 24 & Tilottoma (NL 1073) & Mexico & 2015 & Terai & 3.2 \\
\hline 25 & Bandganga (BL 3623) & Nepal & 2016 & Terai & 3.3 \\
\hline 26 & Sorgadwari (BL 3629) & Nepal & 2016 & Hills & 4.4 \\
\hline 27 & Munal & Mexico & 2017 & Hills & 5.06 \\
\hline 28 & Chyakhura & Mexico & 2017 & Hills & 3.25 \\
\hline 29 & Khajura Durum 1 & Mexico & 2017 & Mid-western and Far-western Terai & 4.82 \\
\hline 30 & Khajura Durum 2 & Mexico & 2017 & Mid-western and Far-western Terai & 5.26 \\
\hline
\end{tabular}

Released wheat varieties 43/denotified wheat varieties 13/under cultivation 30

\section{Appendix 2}

See Fig. 2. 


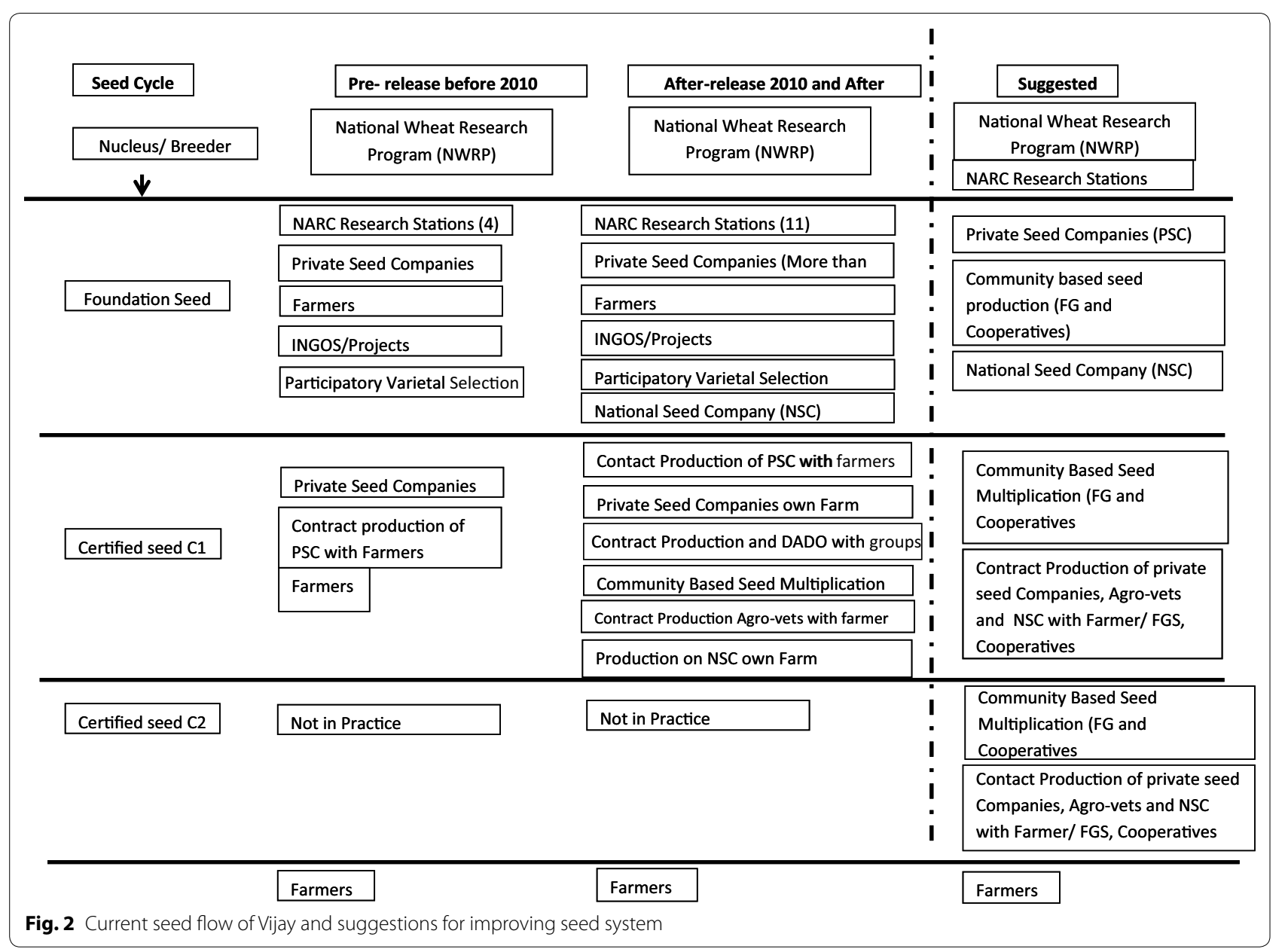

\section{Appendix 3}

See Table 6.

Table 6 Breeder seed production of Vijay variety of wheat in NWRP $(\mathbf{k g})$

\begin{tabular}{|c|c|c|c|c|c|c|c|c|}
\hline Year & BS & FS (estimated) & Estimated C1 & $\begin{array}{l}\text { Estimated } \\
\text { area coverage } \\
\text { by using } \mathrm{C} 1 \mathrm{Vijay} \\
\text { in } \mathrm{Ha}\end{array}$ & Estimated C2 & $\begin{array}{l}\text { Estimated } \\
\text { area coverage } \\
\text { by using c2 Vijay } \\
\text { in } \mathrm{Ha}\end{array}$ & $\begin{array}{l}\text { \% of Estimated } \\
\text { area coverage } \\
\text { by using C1 Vijay } \\
\text { as seed on total } \\
\text { wheat area } \\
\text { in Terai }\end{array}$ & $\begin{array}{l}\% \text { of Estimated } \\
\text { area coverage } \\
\text { by using } \mathrm{C} 2 \mathrm{Vijay} \\
\text { as seed on total } \\
\text { wheat area in Terai }\end{array}$ \\
\hline 2007/08 & 40 & & & & & & & \\
\hline 2008/09 & 402 & 600 & & & & & & \\
\hline 2009/010 & 2940 & 6030 & 9000 & & & & & \\
\hline 2010/11 & 2660 & 44,100 & 90,450 & 75 & 135,000 & & & \\
\hline $2011 / 12$ & 6370 & 39,900 & 661,500 & 753.75 & $1,356,750$ & 1125 & 3.59 & 5.36 \\
\hline 2013/14 & 7600 & 95,550 & 598,500 & 5512.5 & $9,922,500$ & $11,306.25$ & 26.25 & 53.84 \\
\hline $2014 / 15$ & 4150 & 114,000 & $1,433,250$ & 4987.5 & $8,977,500$ & $82,687.5$ & 23.75 & 393.75 \\
\hline 2015/16 & 4850 & 62,250 & $1,710,000$ & $11,943.75$ & $21,498,750$ & $74,812.5$ & 56.88 & 356.25 \\
\hline 2016/17 & & 72,750 & 933,750 & 14,250 & $25,650,000$ & $179,156.25$ & 67.86 & 853.13 \\
\hline $2017 / 18$ & & & $1,091,250$ & 7781.25 & $14,006,250$ & 213,750 & 37.05 & 1017.86 \\
\hline 2018/19 & & & & 9093.75 & $16,368,750$ & $116,718.75$ & 43.30 & 555.80 \\
\hline
\end{tabular}




\section{Publisher's Note}

Springer Nature remains neutral with regard to jurisdictional claims in published maps and institutional affiliations.

Received: 23 February 2018 Accepted: 4 September 2018

Published online: 10 September 2018

\section{References}

1. Abebaw D, Haile MG. The impact of cooperatives on agricultural technology adoption: empirical evidence from Ethiopia. Food Policy. 2003;38(1):82-91.

2. Ainembabazi $\mathrm{JH}$, van Asten P, Vanlauwe B, Ouma E, Blomme G, Birachi EA, Nguezet PMD, Mignouna DB, Manyong VM. Improving the speed of adoption of agricultural technologies and farm performance through farmer groups: evidence from the Great Lakes region of Africa (Article). Agric Econ. 2017;48(2):241-59.

3. Bhatta MR, Joshi AK, Gautam NR, Pokharel DN. Accelerating the adoption of Ug99 resistant wheat cultivars in Nepal. Poster presented during 8th International Wheat Conference and BGRI-Workshop in St. Petersburg, Russia, May 30th-4th June; 2010.

4. Cleaver KM. A strategy to develop agriculture in Sub-Saharan Africa and a focus for the World Bank. World Bank technical paper-Africa technical department series 2013, Washington DC, USA. 1993. http://dx.doi. org/10.1596/0-8213-2420-9.

5. David S, Louise S. Improving technology delivery mechanisms: lesson from bean seed systems research in East and Central Africa. Agric Hum Values. 1999;16:381-8.

6. Etwire E, Ariyawardana A, Mortlock MY. Seed delivery systems and farm characteristics influencing the improved seed uptake by smallholders in Northern Ghana. Sustain Agric Res. 2016;5(2):27-40.

7. Gauchan D. Pattern of adoption and farm level diffusion of modern rice varieties in Nepal. In: Bhandari DR, Khanal MP, Joshi BK, Acharya P, Ghimire $\mathrm{KH}$, editors. Rice science and technology in Nepal (MN Paudel. Khumaltar: Published by Crop Development Directorate (CDD), Hariharbhawan and Agronomy Society of Nepal (ASoN); 2017. p. 639-44.

8. Gauchan D, Dongol D. Country report for wheat expert elicitation study, CIMMYT NARC Collaborative Study for Varietal Release and Adoption Data (2014). Strengthening Impact Assessment in CGIAR (SIAC) Project. Nepal Agricultural Research Council (NARC), Kathmandu, Nepal; 2015

9. Gauchan D, Thapa Magar DB, Gautam S. Marketing of hybrid rice seed in Nepal: recent evidence from field survey. Socio- Economics and Agricultural Research Policy Division (SARPOD), Nepal Agricultural Research Council, Khumaltar, Lalitpur, Nepal; 2014.

10. Gauchan D, Singh S, Tripathi BP, Singh US. Policy workshop on development of Seed-Net in Nepal. A synthesis report of workshop on "Seed-Net Development" jointly held by IRRI and NARC on 23 December, 2011, Hotel Mountain, Kathmandu, Socioeconomics and Agricultural Research Policy Division, Nepal Agricultural Research Council, Nepal; 2014.

11. Gauchan D, Timsina KP. Tracking seed flow, varietal adoption and initial farm level impact of Improved UG99 Resistant Variety (BL 3063) in Nepal Terai. Technical report Submitted to CIMMYT, Kathmandu, Nepal; 2012.

12. Gautam S, Panta HK, Yelasco ML, Ghimire YN, Gauchan D, Pandey S. Tracking of improved rice varieties in Nepal. Country report for rice component of the project "Tracking of improved varieties in South Asia" Monograph. International Rice Research Institute, Philippines; 2013.

13. Ghimire YN, Pokharel TP, Khadka R. Lessons learned from the experiences of the scaling-up programme of the Nepal Agricultural Research Council. In: Proceedings of a workshop on uptake pathways and scaling up of agricultural technologies to enhance the livelihoods of Nepalese Farmers. Hill Agriculture Research Project (HARP); 2003. p. 137-144.

14. Government of Nepal (GoN). National seed vision (seed sector development strategy 2013-2025). Government of Nepal, Ministry of Agricultural Development, National seed Board, Seed Quality Control Center; 2013.

15. International Maize and Wheat Improvement Center (CIMMYT). Wheatglobal alliance for improving food security and the livelihood of the resource-poor in the developing world. A Draft proposal Submitted by CIMMYT and ICARDA, to the CGIAR Consortium Board; 2010.
16. Joshi AK, Azab M, Mosaad M, Moselhy M, Osmanzai M, Gelalcha S, Bedada G, Bhatta MR, Hakim A, Malaker PK, Haque ME, Tiwari TP, Majid A, Jalal Kamali MR, Bishaw Z, Singh RP, Payne T, Braun HJ. Delivering rust resistant wheat to farmers: a step towards increased food security. Euphytica. 2010;179:187-96.

17. Ministry of Agriculture Development (MOAD). Statistical information on Nepalese Agriculture 2015/2016. Agri Statistics Section, Monitoring, Evaluation and Statistics Division, Ministry of Agricultural Development, Singha Durbar, Kathmandu, Nepal; 2017.

18. Ministry of Agriculture Development/Department of Agriculture (MOAD/ DOA). Krisi Diary. Ministry of Agriculture and Cooperative/Department of Agriculture/Agriculture information and Communication centre, Hariharbhawan, Lalitpur; 2016.

19. National Wheat Research Program (NWRP). Annual report 2010/11. Published by NWRP, Bhairahawa, Rupandehi; 2011

20. Niangado, O. Varietal developmental and seed system in West Africa: challenges and opportunities. Second Africa Rice Congress. Bamako, Mali, 2010. Retrieved from http://www.africarice.org/workshop/ARC/0p1\%20 Niangado\%20fin.pdf.

21. National Wheat Research Program (NWRP). Annual report $2008 / 09$ to 2009/10. Published by NWRP, Bhairahawa, Rupandehi; 2010.

22. Nepal Agricultural Research Council (NARC); NARC's Strategic Vision for Agriculture Research (2011-2030); 2010.

23. Nepal Agricultural Research Council (NARC). Seed compilation report. Published by Monitoring and Evaluation Division, Nepal Agricultural Research Council, Singha Durbar Plaza, Kathmandu, Nepal; 2016.

24. Poolsawas S, Napasintuwong O. Farmer innovativeness and hybrid maize diffusion in Thailand. J Int Agric Ext Educ. 2013;20(2):50-63.

25. Shrestha HK, Manandhar HK, Regmi PP. Variety development cost versus variety adoption in major cereals in Nepal. Nepal J Sci Technol. 2012;13(1):7-15.

26. Simtowe F, Asfaw S, Abate T. Determinants of agricultural technology adoption under partial population awareness: the case of pigeon pea in Malawi. Agric Food Econ. 2016;4:7.

27. Socio-Economics and Agricultural Research Policy Division (SARPOD) Annual report (2011/12). Published by SARPOD, Khumaltar, Lalitpur, Nepal; 2012.

28. Socio-Economics and Agricultural Research Policy Division (SARPOD) Annual report (2012/13). Published by SARPOD, Khumaltar, Lalitpur, Nepal; 2013.

29. Socio- Economics and Agricultural Research Policy Division (SARPOD) Annual report (2014/15). Published by SARPOD, Khumaltar, Lalitpur, Nepal; 2015.

30. Thapa M, Acharya LP, Thapa B. Existing seed policies, seed regulatory frameworks and quality assurance systems in Nepal: ways forward. In: proceeding of the Fourth National Seed Seminar held from 19-20 June, 2008. Published by Government of Nepal, Ministry of Agriculture Cooperatives, National Seed Board, Hariharbhawan, Pulchowk, Lalitpur; 2008. p. 6I-76.

31. Timsina KP, Gairhe S, ThapaMagar DB, Ghimire YN, Gauchan D, Padhyoti Y. On farm research is a viable means of technology verification, dissemination and adoption: a case of wheat research in Nepal. Agron J Nepal. Published by Agronomy Society of Nepal (ASoN) and Crop Development Directorate (CDD), Department of Agriculture (DoA), Kathmandu. 2016: 4:9-24.

32. Timsina KP, Gairhe S, ThapaMagar DB, Ghimire YN, Gauchan D, Padhyoti Y. Effectiveness of on Farm research: Evidence of wheat research in Nepal. Government of Nepal, Nepal Agricultural research Council (NARC), Socioeconomics and Agricultural Policy Research Division, Lalitpur, Nepal; 2016.

33. Timsina KP, Bastakoti RC, Shivakoti GP. Achieving strategic fits in onion seed supply chain in Nepal. J Agribus Dev Emerg Econ. 2016;6(2):127-49.

34. Timsina KP, Shivakoti GP, Bradford KJ. Supply situation of vegetable seeds in Nepal: an analysis from policy perspective. J Nepal Hortic. 2015:2015(10):26-36.

35. Timsina KP, Shrestha KP, Pandey S. Factors affecting adoption of new modern varieties of Rice in eastern Terai of Nepal. In: The Proceedings of 4th Society of Agricultural Scientist-Nepal (SAS-N) conference held at Lalitpur 4-6 April, 2012. Published by Nepal Agricultural Research Council (NARC) \& Society of Agricultural Scientists (SAS-N), Nepal; 2012. p. 48-54.

36. Velasco ML, Tsusaka TW, Yamano T. Tracking of improved varieties in South Asia (TRIVSA). TRIVSA Synthesis Report on Rice. International Rice Research Institute (IRRI). Los Banos, Philippines; 2013. 